Original Research Paper

\title{
On the Problem of Stratigraphic Assignment of the Key Seismic Horizons on the East-Arctic Shelf and in the Area of Central Arctic Uplifts
}

\author{
${ }^{1}$ Lidia Daragan-Sushchova, ${ }^{1}$ Lyudmila Grinko, ${ }^{2}$ Natalia Petrovskaya and ${ }^{3}$ Yuri Daragan-Sushchov \\ ${ }^{1}$ Department of Lithogeodynamics and Metallogeny of Sedimentary Basins, \\ FSUE “A.P. Karpinsky Russian Geological Research Institute” (VSEGEI), Saint Petersburg, Russia \\ ${ }^{2}$ Department of Geological, "Dalmorneftegeophysica" JSC, Yuzhno-Sakhalinsk, Russia \\ ${ }^{3}$ Department of System Geological-Geophysical Research, \\ FSUE VNIIOkeanologia Named After I.S. Gramberg, Saint Petersburg, Russia
}

Article history
Received: 09-02-2015
Revised: 07-04-2015
Accepted: 30-04-2015
Corresponding Author:
Lyudmila Grinko
Department of
Lithogeodynamics and
Metallogeny of Sedimentary
Basins, FSUE “A.P. Karpinsky
Russian Geological Research
Institute"(VSEGEI), Saint
Petersburg, Russia
Email: lyudmila_grinko@vsegei.ru

\begin{abstract}
Modern geological and geophysical studies of Central Arctic uplifts area and East-Arctic Shelf has revealed the basic problems in stratigraphic subdivision of sedimentary cover. Basic approach for subdivision of Arctic Ocean sedimentary cover is based on the wave field's characteristics and tracing of regional seismic horizons. Their age identification still depends on general geological ideas. Different correlative models of seismic-stratigraphic units and their ages are given in this study for different Arctic regions. The following regions were selected for analyses: Cis-polar part of the Lomonosov Ridge and zone of its connection with the Amundsen and the Makarov basins, profile CDP A7, located in the transition zone of the Lomonosov Ridge, the Russian Shelf and the North-Chukchi shelf trough.
\end{abstract}

Keywords: Arctic Ocean, Seismic Reflection Method Common Midpoint (CDP), Age of Seismic-Stratigraphic Units

\section{Introduction}

Significant number of modern seismic surveys was carried out in the last years on the East-Arctic Shelf, including the shelf of the Laptev, the East Siberian and the Chukchi Seas (Fig. 1). The dredging of the rock material was done on some parts of underwater uplifts in order to provide information for the understanding of geological history of the Central Arctic area and in whole the problem of the Arctic Ocean (AO) origin. The deep-water drilling at the Lomonosov Ridge (well ACEX-302) in vicinity to the North Pole played key role in stratigraphic subdivision of Cenozoic deposits of the ocean and its shelf. Not only petrographic characteristics of material composition of well's layer-by-layer sequence were acquired but also the paleontological description of fossils. New information allows dating the sediments and correlating them with regional Reflecting Horizons (RH), revealed by seismics just from the first studies in the region. The additional information was provided by the deep wells, drilled in the American part of the Chukchi Sea. The composite sections of ACEX302 well from the Lomonosov Ridge and wells on the
Chukchi Sea shelf are the basis for stratigraphic assignments of the reflecting horizons.

The progress in geological and geophysical studies of the Central Arctic uplifts area has revealed the basic problems in subdivision of Quasi-Synchronous SeismicStratigraphic Sequences (QSSS), correlation of Reflection Horizon (RH) and its age determination.

Notwithstanding on relatively good seismic data, there are only few profiles in the deep water part of the AO executed with reflected wave method CDP on the big offset basis. Among them are the following: A7 along the south part of the Lomonosov Ridge Arc12-03, Arc12-19 in the deep-water part of the of the Central Arctic uplift area and a part of Arc12-16 on the SouthEast part of the Eurasianbasin and on the south of the Lomonosov Ridge. In the last years good modern CDP regional profiles were collected on the shelf of the EastSiberian, Chukchi and Laptev seas. The rest of regional profiles were run off under Trans-Arctic programs and Arctic 2005, 2007 and 2011 geotraverses with point and two-dimensional CDP surveys with relatively short source-receiver offset. 


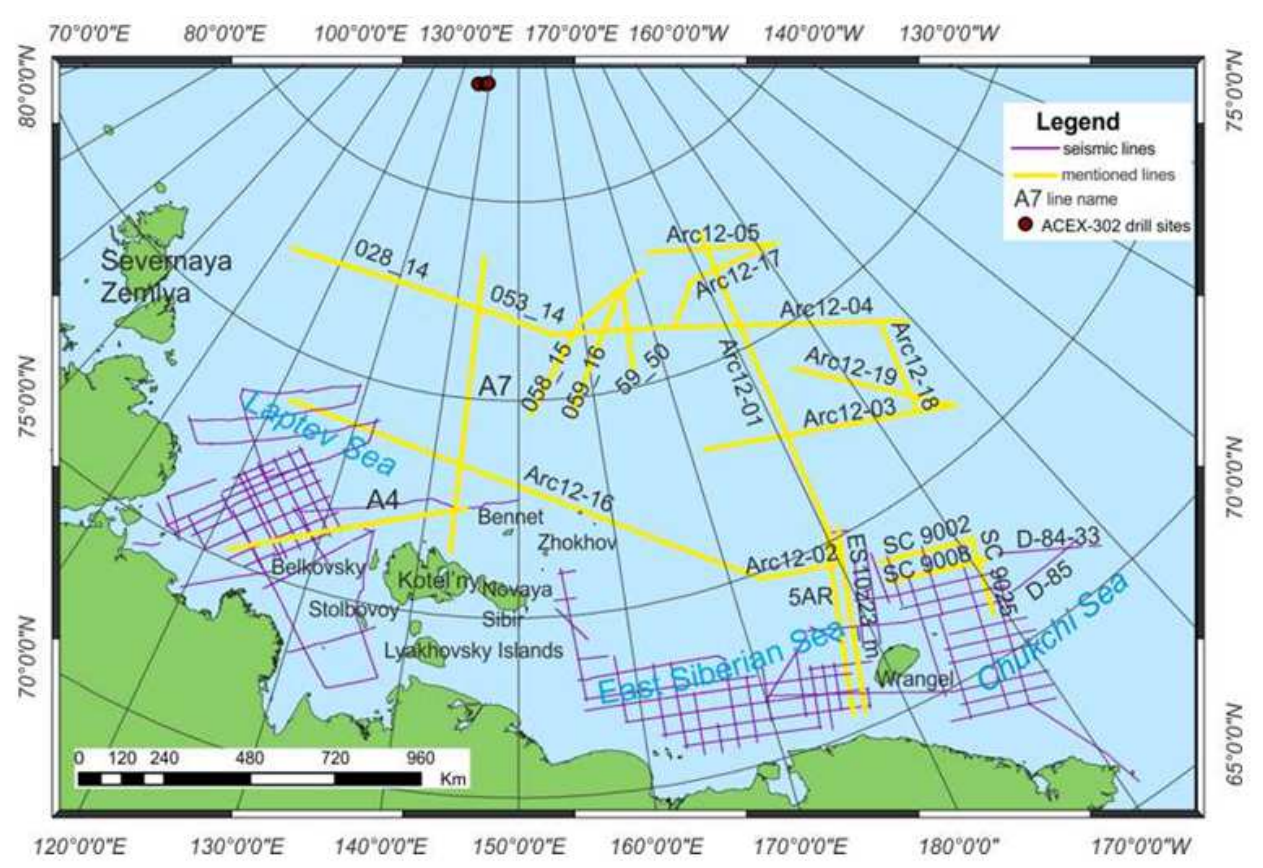

Fig. 1. Seismic lines database used on the East Arctic shelf and the Central Arctic uplifts

There are no stratigraphic wells in the ocean at all. The stratigraphic correlation of RH within the deepwater part of the AO is still quite unclear due to the absence of geological markers. General approach for stratigraphy of the AO sedimentary cover is based on the wave field's characteristics and RH tracing. So its stratigraphic attribution still depends on general understanding of geology. More specifically, tracing of regional RH from the basins onto the uplifts and ridges is often impossible due to various hypsometric position of structures (bottom depth fall may reach $1.5 \mathrm{~km}$ and more) and presence of vast zones at steep uplift flanks lacking any correlation. An additional characteristic which is considered while correlation of QuasiSynchronous Seismic Sequences (QSSS) is the distribution of layer velocity along the seismic section which are surely not the attributes of own stratigraphy but carry the important information about physical peculiarities of the studied formation.

\section{Materials and Methods}

In the Lomonosov Ridge's part adjacent to the North Pole and in the zones of its junction with the Amundsen and Makarov basins there are several models of geological structure which differ in thickness of the identified seismic-stratigraphic units and stratigraphic correlation to the ACEX 302 well. According to V.V. Butsenko's model (Butsenko and Poselov, 2004; Butsenko, 2008) the main regional marker in seismic section of the Makarov and Amundsen basins and the Lomonosov Ridge is RH RU (or LS2), which correspond to the Oligocene hiatus. This boundary, judging by the core from well ACEX 302, is associated with the change of shallow-water conditions of sedimentation to deepwater ones, which took place according to biostratigraphic data 20-26 M.y. before in the Eocene-Early Miocene interval (Backman et al., 2006). According to estimation of other researchers, within 12.4 M.y. in the period between the end of the Oligocene and the Middle Pliocene (Kim and Glezer, 2007). The authors of this model believe that the seismic pattern of such global event like changing of sedimentation environment shall be seen in the major part of the Central-Arctic uplift province (including the Makarovbasin). At the Lomonosov Ridge this RU has erosive nature. This model is supported by the data of B.I. Kim concerning regional formation of chemical weathering in the interval between the Late Oligocene and the Early Miocene in the continental and island surroundings of the Amerasianmegabasin.

One may note that neither horizon RU, nor the underlying deposits bear typical erosion signs. All the Cenozoic part of section here is represented by clays and silty ooze, has characteristic thin horizontal bedding and was developed under the conditions of weak tectonic down warping regime. There are no signs of hiatuses in the sedimentary section and a "zebra" (Butsenko and Poselov, 2004; Butsenko, 2008) horizon which corresponds to $\mathrm{RH} \mathrm{RU}$, divides the covered by the drilled part of the section into two structurally equal parts which differ only by numerical diatom distribution. The layer velocities gently increase from 1.6-1.8 to 2.0$2.2 \mathrm{~km} \mathrm{~s}^{-1}$. On the boundary of RH RU, where erosion of 
Oligocene-Early Miocene sediments is supposed to occur, there is no abrupt change in the layer velocity.

According to another model (Rekant and Gusev, 2012), the brightest seismic marker in the section of the arch part of the Lomonosov Ridge is the regional erosion and angular unconformity LU (or LS1) associated with the lowest part of the well and dated according to micropaleontologic data to be Late Miocene. The angular unconformity LU (Jokat et al., 2005) is correlated with the block stage of the ridge development which was accompanied with great gap in sedimentation, erosion of sediments on the crest zone of the ridge and active tectonic movements. Notwithstanding that the referred interval is not described by core, it is supposed that this horizon consisted of poorly consolidated sand, washed out while the well was drilled. The reflection horizon LU is also traced on the significant area of the Amerasianmegabasin and correlated by author's model with RU of the adjacent Podvodnikov and the Amundsen basins. It is remarkable that according to B.I. Kim data, thick chemical weathering crusts are also developed in the Upper Cretaceous and Pliocene at the Amerasianmegabasin continental margin.

The authors are correctly convinced that regional tectonic events, occurred in the area of the Central Arctic uplifts, should have principally different reflections in the uplifts and deep-water basins. The former were eroded out and served as source area, when the latter were deposition centers where large volume of eroded deposits was accumulated. Therefore, the erosive contact of the Ridge should be correlated with the sedimentary complex of adjacent basin which has the fullest sequence. The stratigraphic section on the ridges is reduced and it is natural that its consideration as the key section means multiplication of the problem of incompleteness of geological record. It is pointed that there is sharp increase of layer velocity at the RH LU mark, low-velocity non-lithified Cenozoic deposits lies directly on the eroded roof of high-velocity deposits, which prove the validity of the suggested correlation of $\mathrm{RH}$ LU on the Lomonosov Ridge with RH RU in the adjacent basins. Complex clino form seismic series are traced between low-velocity and high-velocity seismic sequences at the north and west parts of the ridge. It proves the removal of eroded sediments of the ridge and its accumulation in the local sediment traps as well as adjacent deep-water basins. Previously a similar sediment succession in the graben at east slope of the Lomonosov Ridge was described by (Kim and Gleser, 2007).

There are other options for RH correlation, which are based on wave pattern similarity of seismic sequences on the uplifts and adjacent basins and also on the magneticstratigraphy dating (Langinen et al., 2009; Chernih and Krylov, 2011). Various approaches to RH correlation in the adjacent morphostructures on the relatively small area show the evident necessity to drill deep wells in the
Arctic and mostly in the basins where the sedimentary cover is the fullest meaning that complete sedimentary record of region's geological evolution is buried here.

Profile CDP A7, located in the connection zone of the Lomonosov Ridge and the Russian Shelf, is an evident illustration of seismic stratigraphy correlation possibilities. Sedimentary cover QSSS and RH are traced continuously over nearly $800 \mathrm{~km}$ along the shelf and northwards through the continental slope along the ridge and partially slope part of the Lomonosov Ridge starting almost from Kotelniy Island of the Novosibirsk grabens and horsts system (Fig. 2). In the sedimentary cover of the profile a series of seismic sequences and $\mathrm{RH}$ were identified. The two most pronounced of them are acoustic basement and regional unconformity LS2 (Franke et al., 2001), according to horizon indexation of the Marine Arctic Geophysical Expedition (MAGE). The sediments thickness above the unconformity gently grows from shelf to continent slope forming the progradation prism but further northwards it decreases again to $0.5-1.0 \mathrm{~km}$ on the ridge crest. The thickness of sedimentary layer between the acoustic basement and regional unconformity changes significantly by increasing up to $8-10 \mathrm{~km}$ in the shelf troughs and by decreasing up to $0.5-2.0 \mathrm{~km}$ in the local shelf rises and on the Lomonosov Ridge.

Age determination of selected seismic horizons at the present research stage may be performed only based on indirect data, as there are no wells in the area of the Lomonosov Ridge connection with the shelf. It is impossible to tie shelf QSSS to definite formation of Novosibirsk islands cover-here there were no changeof shallow deposits by deep-water deposits and Cenozoic islands cover formations as a rule have lower thickness than seismic resolution capability. We may suppose that the age of regional unconformity LS2 is the Late Eocene-Early Miocene. In this period of time, i.e., at least during all Oligocene, there was no sediments accumulation on the Lomonosov Ridge. Regional hiatus in sedimentation at the Beaufort Sea was in the middle Miocene (5-6-th anomalies of the Lamont scale). Here in the wells not only erosion is noted but also angular unconformity (Enachescu, 1990). Correspondence of paleostructure frame of Miocene and PlioceneQuaternary formations of the Laptev continental margin to its modern structure is a firm evidence of the Miocene age of the unconformity (Daragan-Sushchov et al., 2004). Palaeoreconstruction of the Laptev Sea sedimentary cover shows that the system of the Novosibirskgrabens and horsts was developed not prior to Middle Miocene. By the end of Miocene the tectonic activity had finished. Laptev Sea basin underwent an uplift and erosion which changed by sagging at the beginning of Pliocene. The overlying PlioceneQuaternary basin sequence with regional unconformity transgressively overlaps all the Laptev Sea, resting horizontally on the sedimentary formations of various 
ages (Daragan-Sushchova et al., 2010). Thusonly in Miocene (especially from Pliocene) appear an evident shelf, continental slope and natural deep-water trough of the Eurasian basin of the AO. This is definitely follows from the picture of the wave field and correlation of the upper seismic sequence formations at profile A 7. The age of acoustic basement on the south end of the profile is specified more exactly. According to refined data acquired by All-Russian Geological Institute (VSEGEI) in 2011-12 on Novosibirsk islands, the sequence of platform sedimentary cover, which is traced by seismic methods on the shelf, starts from the Early Cretaceous (Aptian-Albian).deposits of Early Cretaceous. Then the age of the lowermost sequence between regional unconformity LS1 and acoustic basement is Early Cretaceous (Aptian)-Paleocene and the age of overlapping sequence located between LS1 and LS2 is the EoceneOligocene, maybe Early Miocene. In the wave field of the lowest sequence in the shelf basins and continental slope one can identify at least 2 subsequences divided by unconformities (RH LS1-1 and LS1-2). The two lowest ones are represented by clear, stratified wave field with lens-shaped bodies with high- intensity which is typical for magmatic intrusions into clastic deposits. General thickness of subsequences is 500-1600 m. Such characteristics are well correlated with the volcanic-clastic Aptian Low Cretaceous deposits observed at Kotelny Island. The upper subsequence has intensively stratified wave field which is typical for carbonate clastic sediments formed in the shallow sea conditions under paralic regime. Its general thickness in the troughs is up to $1000 \mathrm{~m}$. Near the foot of modern continental slope SP 24000-30000 the thickness of subsequence increases in 1.5-2 times, reaching 1.5-2.0 km (Fig. 2).

According to dredging results the basement of the Lomonosov Ridge is mainly consists of clastic and carbonaceous Palaeozoic rocks. The acoustic basement on the shelf and Novosibirsk islands is pre-Lower Cretaceous (up to $\mathrm{K} 1 \mathrm{a}-\mathrm{al}$ ). It seems probable that it is composed of stratified platform clastic and carbonate Palaeozoic-Early Mesozoic formations which were dislocated in the pre-Aptian-Albian age. The relic stratification observed in lower RH A proves this fact. According to wave fields of profile A7, the Verkhoyansk fold belt is extended into ocean. The Palaeozoic and Early Mezozoic stratified sedimentary formations on the profile A7 are the acoustic basement and are not distinguished by seismic methods and thus the Verkhoyansk Mesozoids compose the acoustic basement of the Lomonosov Ridge and its junction zone with shelf. From here comes the geometric similarity of Novosibirsk islands and the Lomonosov Ridge-the west flank of both structures is 2 times narrower than the east one, it has much contrast and rigid relief. These data likely shows that the Lomonosov Ridge is the extension of the Verkhoyansk Mesozoids in the ocean. The example of uncertainty in determination of section stratigraphic fullness on the shelf is a seismic section of the North-Chukchi trough. Different researchers give various correlations to $\mathrm{RH}, \mathrm{QSSS}$ and its age correlation of these two close profiles 5-AP and ES 10Z23 m with fine stratified section. It happens despite the relatively closely located deep wells, which were drilled in the thoroughly studied part of the Chukchi Sea. Thus according to researchers from Dalmorneftegeophysica.

(DMNG, Yuzhno-Sakhalinsk) the acoustic basement in the syncline fold and north flank of trough is drawn at the boundary of the Lower and Upper Ellesmerian and the sedimentary cover is composed of the deposits from the upper Permian to Cenozoic inclusively. On the south flank (within the limits of the North-Wrangel Carboniferous-Middle Jurassic trough) the basement is established at the bottom of the Lower Ellesmerian and stratigraphic volume of the sedimentary cover includes the deposits from Carboniferous to Cenozoic. At the same time colleagues from Sevmorgeo (St. Petersburg) suggested the basement in the bottom of the overlying Beaufort sequence at the Upper Jurassic base (Fig. 3). Besides, the volume of Cretaceous deposits is also considered variously. The researchers from DMNG estimate that volume of Early Cretaceous sediments is 2 times exceed that of the Late Cretaceous, while geologists from Sevmorgeo have completely opposite opinion. The researchers DMNG take the analysis of wave fields and kinematic characteristics of referenced QSSS of the North-Chukchi trough and the Hanna Trough as a basement for such correlation, i.e., the prevailing argument is similarity of geophysical parameters of the section. The geologists of Sevmorgeo believe that both troughs have different ages, on the basis of Wrangel Island geology where Triassic deposits are folded and on general plate tectonic schemes. Geological point of view is the main argument for them.

To solve the problem of correlation and age determination of $\mathrm{RH}$, in our study we combine the wave field of American seismic profile D84-33, kindly given to us by French company «Total», to data from the wells Burger and Popcorn-1. Profile D84-33 is located in 3.7 $\mathrm{km}$ from the well Burger and $0.5 \mathrm{~km}$ from the Popcorn-1 (Fig. 4). The intensive 4-5 phase wave, connected with the Aptian deposits of Lower Cretaceous is identified in the upper part of section at the level of $0.3 \mathrm{~s}$ in the area of the Burger well. Though that the seismic wave is affected by plenty faults, it is clearly observed on the whole profile. The series with the top of which this wave is connected is practically completely eroded in the area of the Popcorn-1 well that is supported by geological data obtained from the well. To the north-west from the Popcorn-1 well, the wave from Aptian deposits is traced with just the same characteristics. This is clearly recognized intensive 4-5 phase wave, which is traced in the time 2.7-3.0 s. There are 2 seismic sequences which are located higher than this specific wave up to RH mBU in the west and north-west part of the East block. 


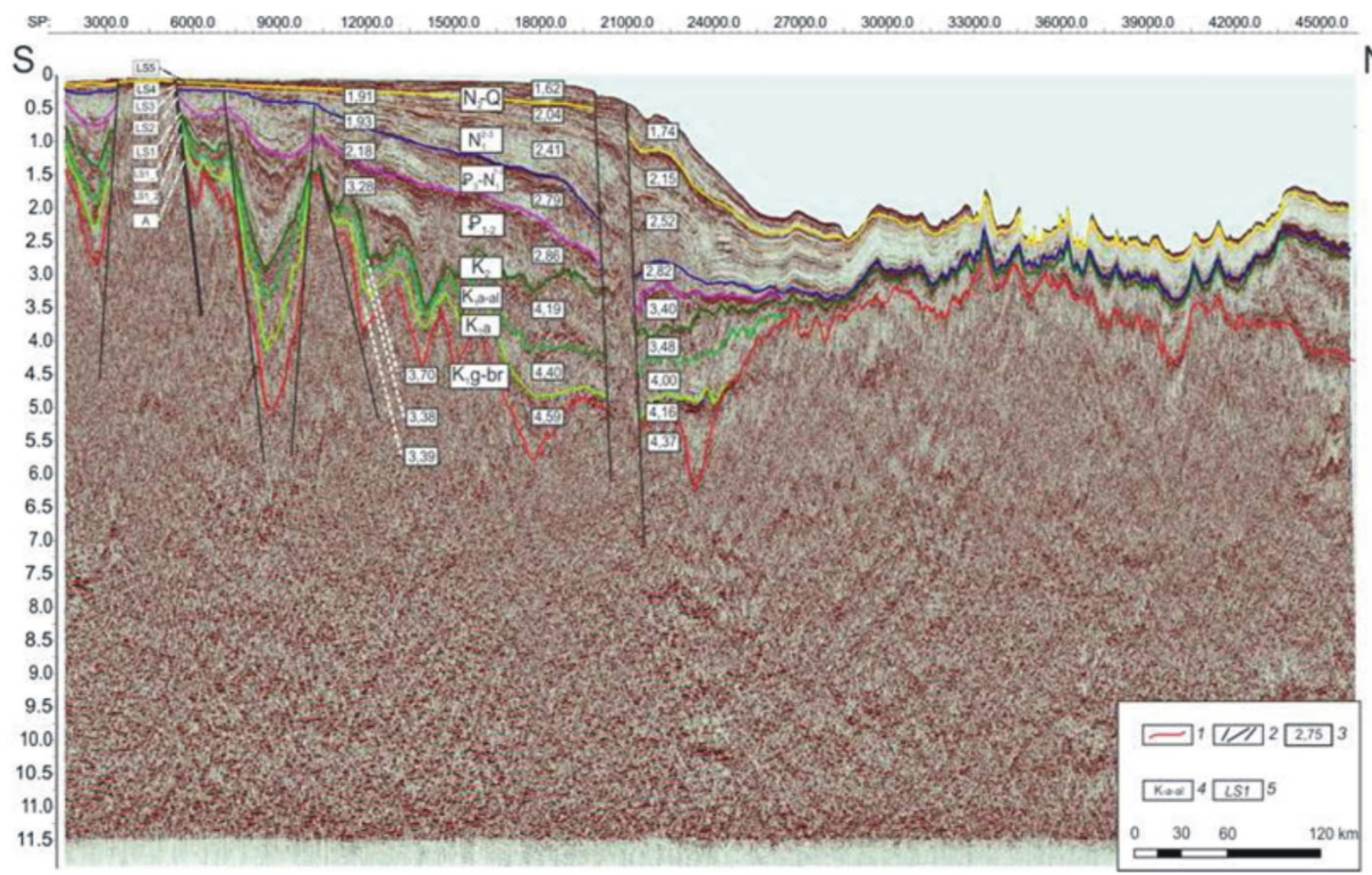

Fig. 2. Reflection-time section of A7 line with layer velocities (MAGE data, interpretation of authors) 1-RH, 2-faults,3-interval velocity, 4-age, 5- RH name

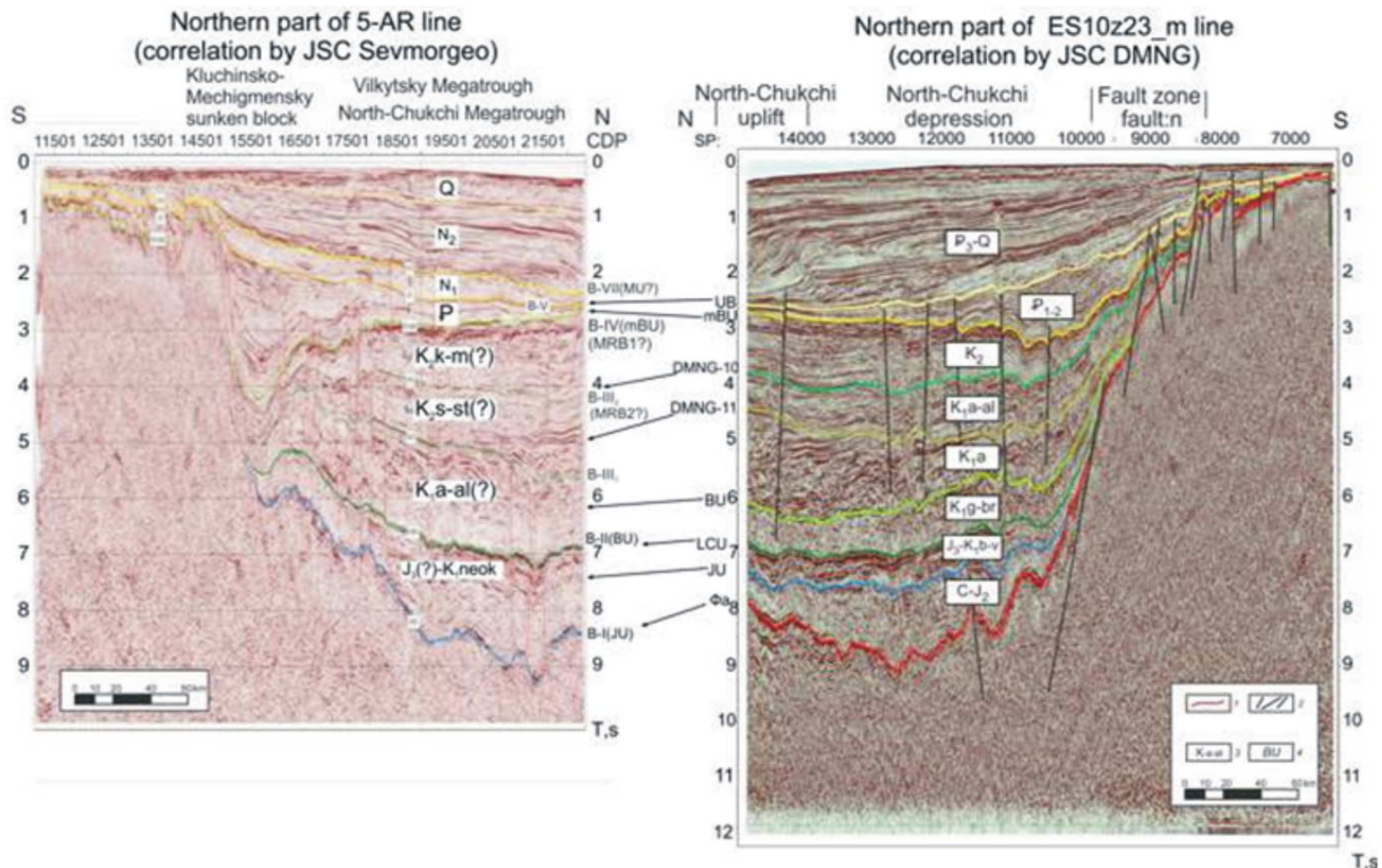

Fig. 3. Comparison of wave field's correlation: 5-AR line (Sevmorgeo) and ES10z23_m (DMNG), 1-RH, 2-faults,3-interval velocity, 4-age, 5- RH name line (location ref. Fig. 1) 


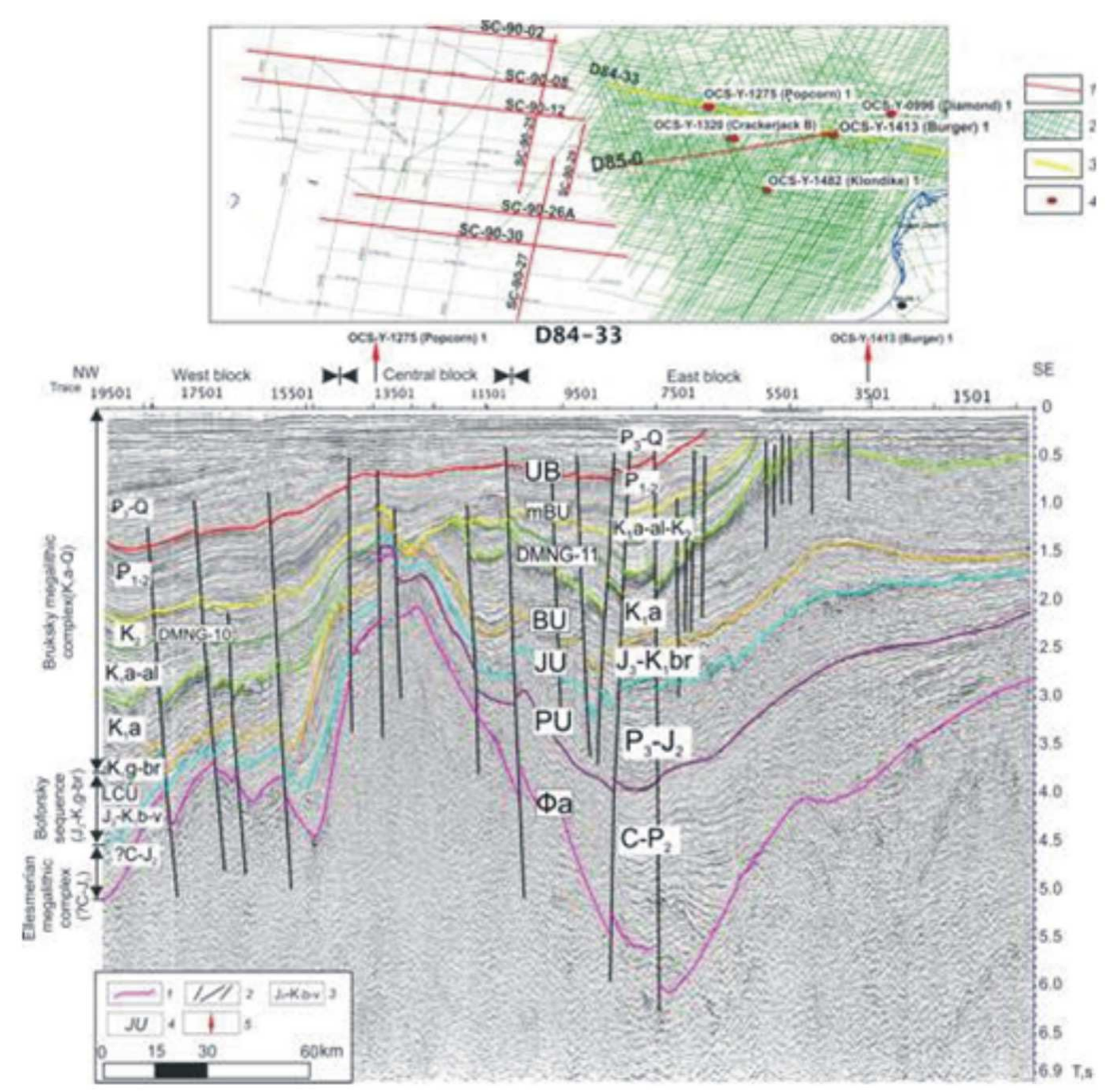

Fig. 4. Reference horizons correlation on the American seismic line through Burger1 and Popcorn 1 wells (Total S.A. data ) 1-RH, 2faults, 3-age, 4- RH name, 5-well position

The lowest one is ascribed to the Albian deposits of Lower Cretaceous and the upper one which is not observed in any well in American sector, is probably related to the Upper Cretaceous deposits. On this profile the correlation of Upper and Lower Cretaceous is the same as was identified by DMNG, i.e., $\mathrm{K} 1$ is in 2 times thicker than K2. In the same way we have correlate the specified wave JU, related to the top of the Upper Ellesmerian sequence. In the area of the Burger well, this intensive rough wave is evidently connected with erosive surface and is observed under stratified series on the 1.7$2.0 \mathrm{~s}$ time, in the Popcorn-1 well-on the times 1.3-1.4 s and in the north-west down dip block it suddenly plunges from 2.1 to $4.5 \mathrm{~s}$, losing its dynamic characteristics, identified on the profile near the wells area. Nevertheless, the wave analysis along all profiles in the North-Chukchi trough area of the Russian sector of the Chukchi and East-Siberian Seas has showed that in the North-Chukchi trough is represented everywhere. In the deepest and near-flank parts of the trough (Fig. 5 and 6 ), it is identified quite reliably. In the central parts of the trough the Ellesmerian sequence thickness may reach 5-6 $\mathrm{km}$. On the flanks of the trough, the sequence becomes thinner; its identification in the seismic field becomes a more complicated. According to the geological data, in the American part of the Chukchi Sea the roof of the acoustic basement divides the metamorphosed Franklinian sequence and sedimentary cover (from upper Devonian to Pliocene) (Sherwood, 2006). It was developed in the beginning of late Devonian in Scandic phase of the Caledonian orogenesis. The basement surface relief is characterized by well pronounced roughness and sudden burial depth fall. On the Wrangel-Gerald uplift the basement crops out into the sea bottom, in the north of the Chukchi Sea it is plunging into depth up to $20-24 \mathrm{~km}$ (profiles ES10Z23 m, ARS10z01) (Fig. 6). 

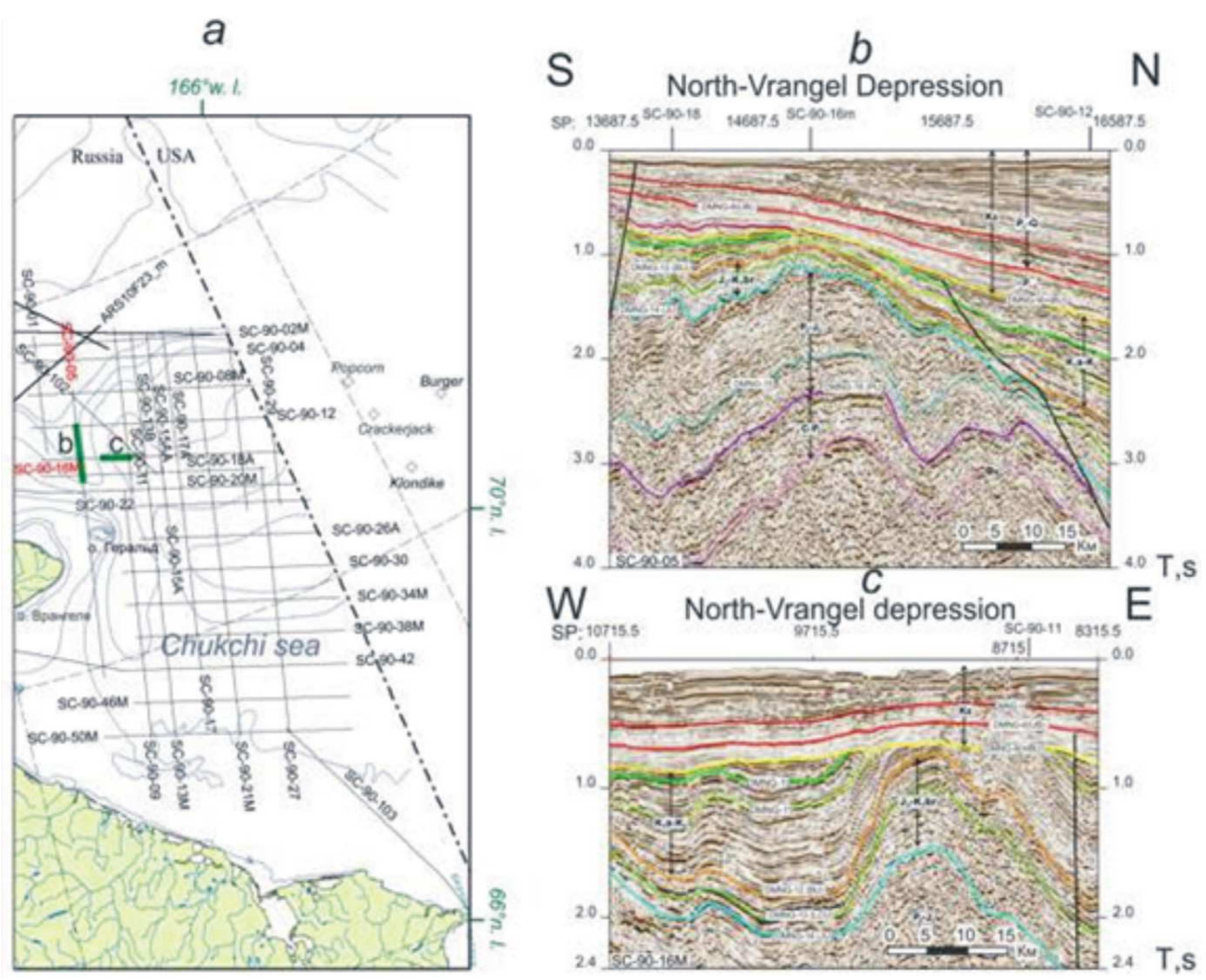

Fig. 5. (a,b,c) Wave field's examples of Ellesmerian sequence in the North-Chukchi shelf with their location: A-location of lines, b,c-wave field's examples with correlation of RH

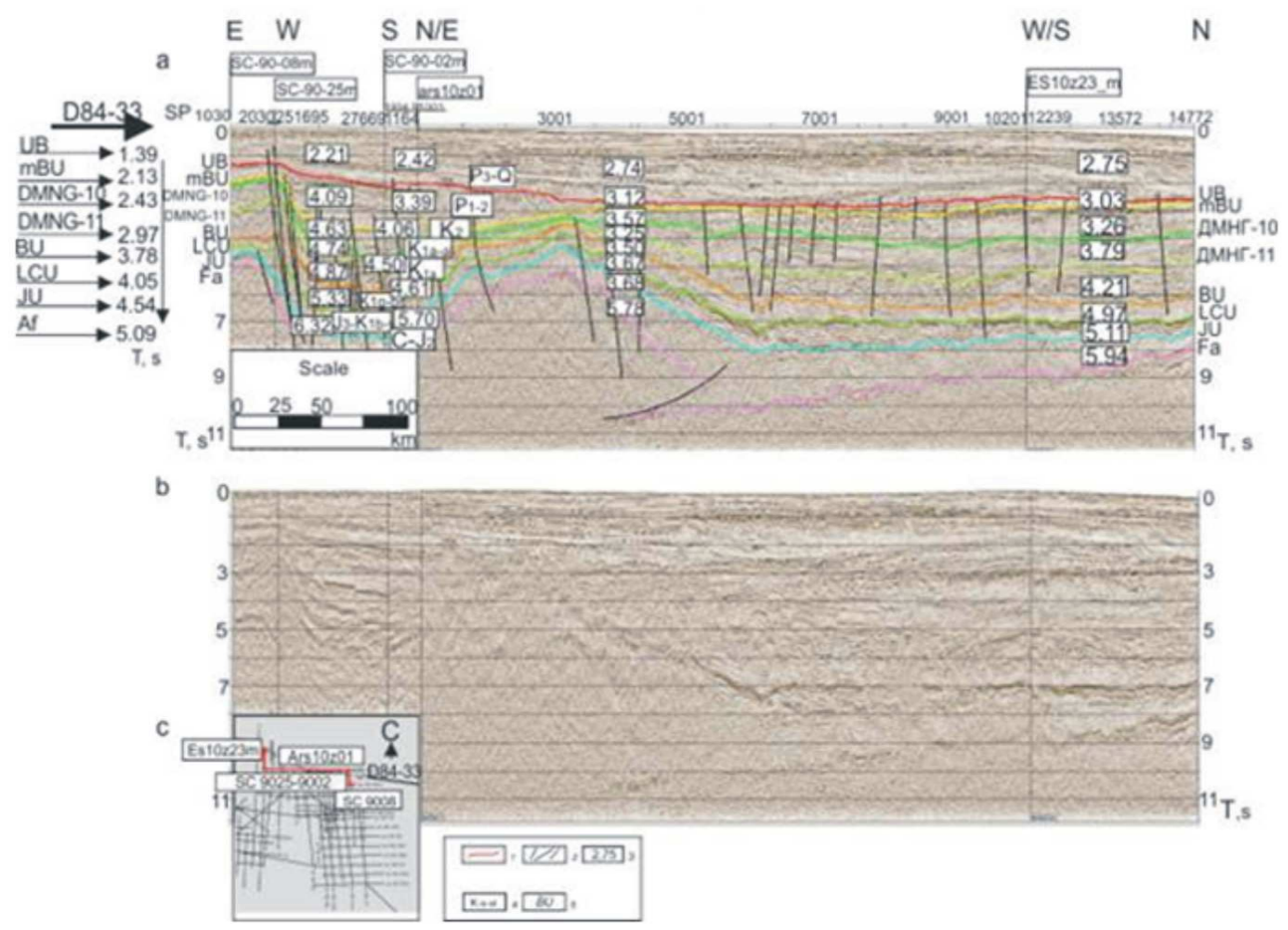

Fig. 6. Composite seismic section from the American D84-33 line through the North of the Chukchi sea shelf to the northeastern part of the East Siberian Sea (SC9008-SC9025-SC9002-Ars 10z01-ES10z23_m): A-with correlation, b-without correlation, c-locat 
The additional information for stratigraphic subdivision and correlation of $\mathrm{RH}$ is provided by kinematic characteristics section. The interval velocities of the American wells were not published. We have information only for some of them, which were estimated by DMNG through calculation (Table 1). It is known that the values of interval velocity may indirectly point to deposits composition in the offshore area. Thus the layer velocity of the Low Ellesmerian sequence with predominantly carbonate composition in the Popcorn-1 well in the interval $2380-3110 \mathrm{~m}$ changes from 3350 to $6100 \mathrm{~m} \mathrm{~s}^{-1}$ with average $4980 \mathrm{~m} \mathrm{~s}^{-1}$ (personal communication of Kirk W. Sherwood).

According to CDP data in the North-Wrangel trough the interval $2995-4379 \mathrm{~m}$ is characterized by $3870 \mathrm{~m} \mathrm{~s}^{-1}$ velocity, interval $3600-5000 \mathrm{~m}-4220 \mathrm{~m} \mathrm{~s}^{-1}$. The values of interval velocity give evidence that a considerable portion of clastic material in the upper part (Carboniferous-Middle Permian) of the Lower Ellesmerian Sequence occurs and points to its relation to calciferous-sandy-siltstone-shale formation which is similar to the one studied at the Cracker Jack well. The debris sources during sequence development were located in the raised area, bordered the North-Wrangel trough from the east (the ChukchiSea) and west (the Shelag and North-Shelag uplifts). The major eroded source was located to the north of the area.

The stratigraphic correlation from the American profile D84-33 was imposed onto a composite profile starting from the nearest seismic profile SC 90-08 $\mathrm{m}$ in the Russian sector of the Chukchi Sea, which is located $32 \mathrm{~km}$ from D84-33 (Fig. 6). Reflection horizons are continuously traced on the composite profile through the whole sedimentary cover, starting from the Ellesmerian sequence (Fig. 6a). It is undoubtedly represented in the North-Chukchitrough, which is supported by dynamic and kinematic characteristics of the sedimentary cover on the whole: Continuous tracing of all sequences with their features, high layer velocities of the 2 lowest sequences. Besides, the dynamics of RH points onto the Caledonian age of basement. It looks like intensive 3-4phase reference reflection which is typical for ancient metamorphosed basement but not to the relatively young Cimmerian as colleagues from Sevmorgeo suggest.

Table 1. Calculated layer velocities of QSSS in the well-area (JSC DMNG data)

\begin{tabular}{|c|c|c|c|c|c|c|c|c|c|c|c|c|}
\hline \multirow{3}{*}{$\begin{array}{l}\text { Complex } \\
\text {-RH }\end{array}$} & \multicolumn{6}{|c|}{ Dix equation } & \multicolumn{6}{|c|}{ Alternative equation } \\
\hline & \multicolumn{3}{|l|}{ Klondike } & \multicolumn{3}{|l|}{ Crackerjack } & \multicolumn{3}{|l|}{ Klondike } & \multicolumn{3}{|l|}{ Crackerjack } \\
\hline & $\mathrm{h}$ & $\mathrm{t}$ & $\mathrm{v}$ & $\mathrm{h}$ & $\mathrm{t}$ & $\mathrm{V}$ & $\mathrm{h}$ & $\mathrm{t}$ & $\mathrm{V}$ & $\mathrm{h}$ & $\mathrm{t}$ & $\mathrm{v}$ \\
\hline mBU-BU & $1249-2542$ & $668-1956$ & 2,78 & $1707-2270$ & $668-1830$ & 2,68 & $1249-2542$ & $668-1956$ & 2,00 & $1707-2270$ & $668-1830$ & 0,96 \\
\hline BU-JU & $2542-2865$ & $1956-2156$ & 3,17 & $2270-2475$ & $1830-1964$ & 3,17 & $2542-2865$ & $1956-2156$ & 3,23 & $2270-2475$ & $1830-1964$ & 3,05 \\
\hline JU-PU & - & - & - & $2475-2627$ & $1964-2084$ & 2,53 & - & - & - & $2475-2627$ & $1964-2084$ & 2,53 \\
\hline PU-Sb & - & - & - & $2627-2918$ & $2084-2180$ & 4,97 & - & - & - & $2627-2918$ & $2084-2180$ & 6,06 \\
\hline JU-Sb & $2865-3660$ & $2156-2604$ & 3,46 & - & - & - & $2865-3660$ & $2156-2604$ & 3,55 & - & - & - \\
\hline
\end{tabular}

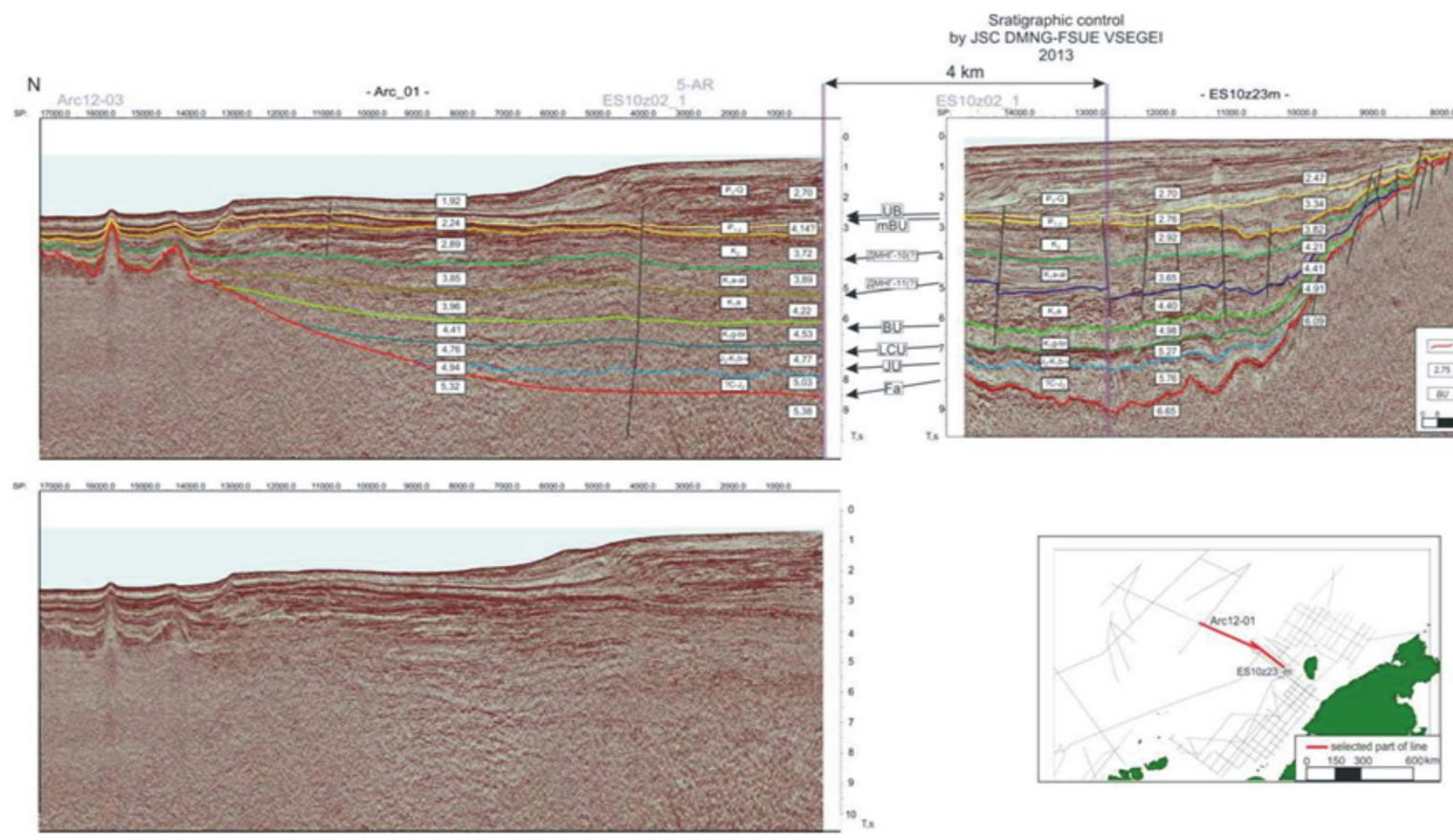

Fig. 7. Composite seismic section Arc12-01-ES10z23_m, 1-RH, 2-faults, 3-interval velocity, 4-age, 5- RH name, 6- profile crossing poin 
Then, the position of key seismic horizons was transferred on the profile Arc12-01 (Fig. 7). Unfortunately this profile was acquired by the less efficient technique (using short seismic streamer) which resulted in the quality of wave field. Nevertheless, upper RH were traced quite accurately and the correlation of the lowest one does not contradict with available wave field and its velocity characteristics along the profiles ES10z23 and ES10z22 m, ES10z02 1, 5-AP, Arc12-03 and correlation refraction probes shot on the profile Arc12-01. In the cross section point the correlation was transferred onto profile Arc12-03. Analyzing the west part of the Arc12-03 profile and comparing it with the wave field of the North-Chukchi trough ES10z23m, ES10z02_1 (Fig. 8), one can suggest their similarity. First, the wave fields of $\mathrm{RH}$ related to the basement are similar. These are intensive 3-4-phase waves rather persistent especially in the most deflected parts of trough. The number of sequences remains the same with some decrease of thickness, depth and change of typical wave field characteristics. Velocities are mainly typical for clastic formations whose values increase with depth (Fig. 9). The lowest sequence is an exception; their layers velocities (Fig. 9) are slightly differ from general relations probably due to some composition change (presence of carbonate or volcanic layers). The major part of the profile Arc12-01 and represented western part of the profile Arc12-03 are located in the AO with bottom depths from 1.5 to $1.9 \mathrm{~km}$, so if we take into account the influence of water layer, the polynomial functions will approximately coincide with polynomial functions along the DMNG lines.

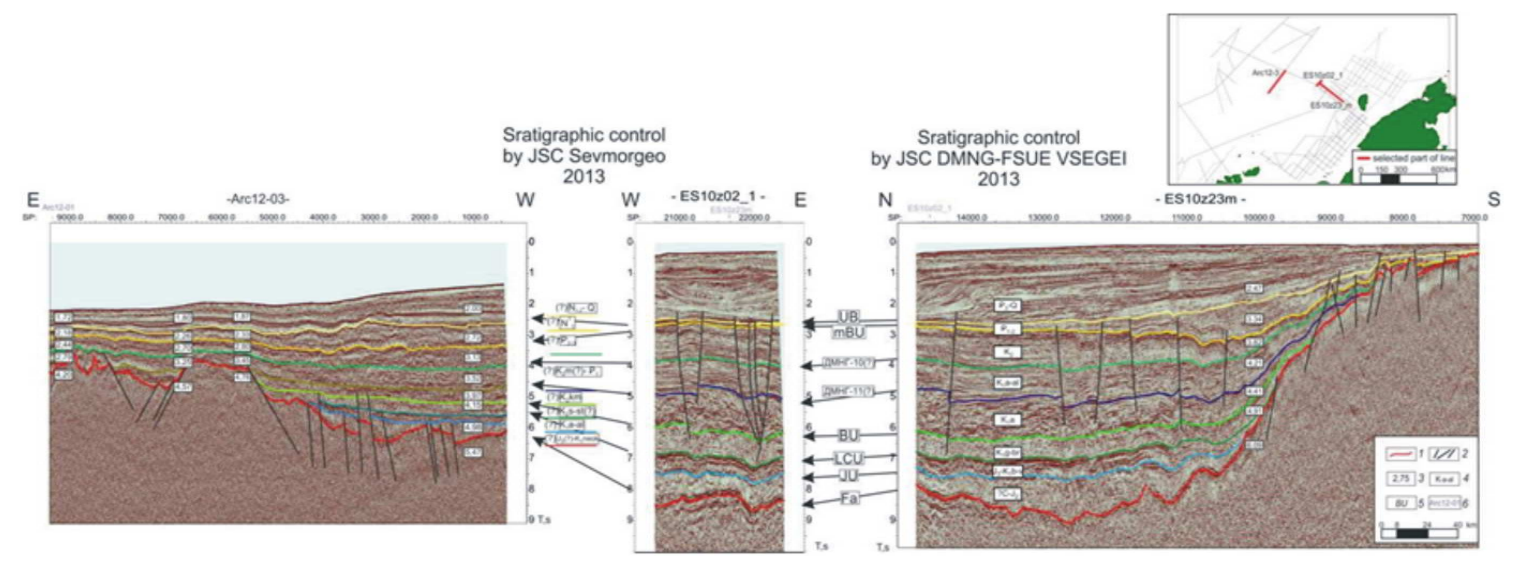

Fig. 8. Composite seismic section Arc12-03-ES10z02-ES10z23_m 1-RH, 2-faults,3-interval velocity,4-age,5- RH name,6profile crossing point

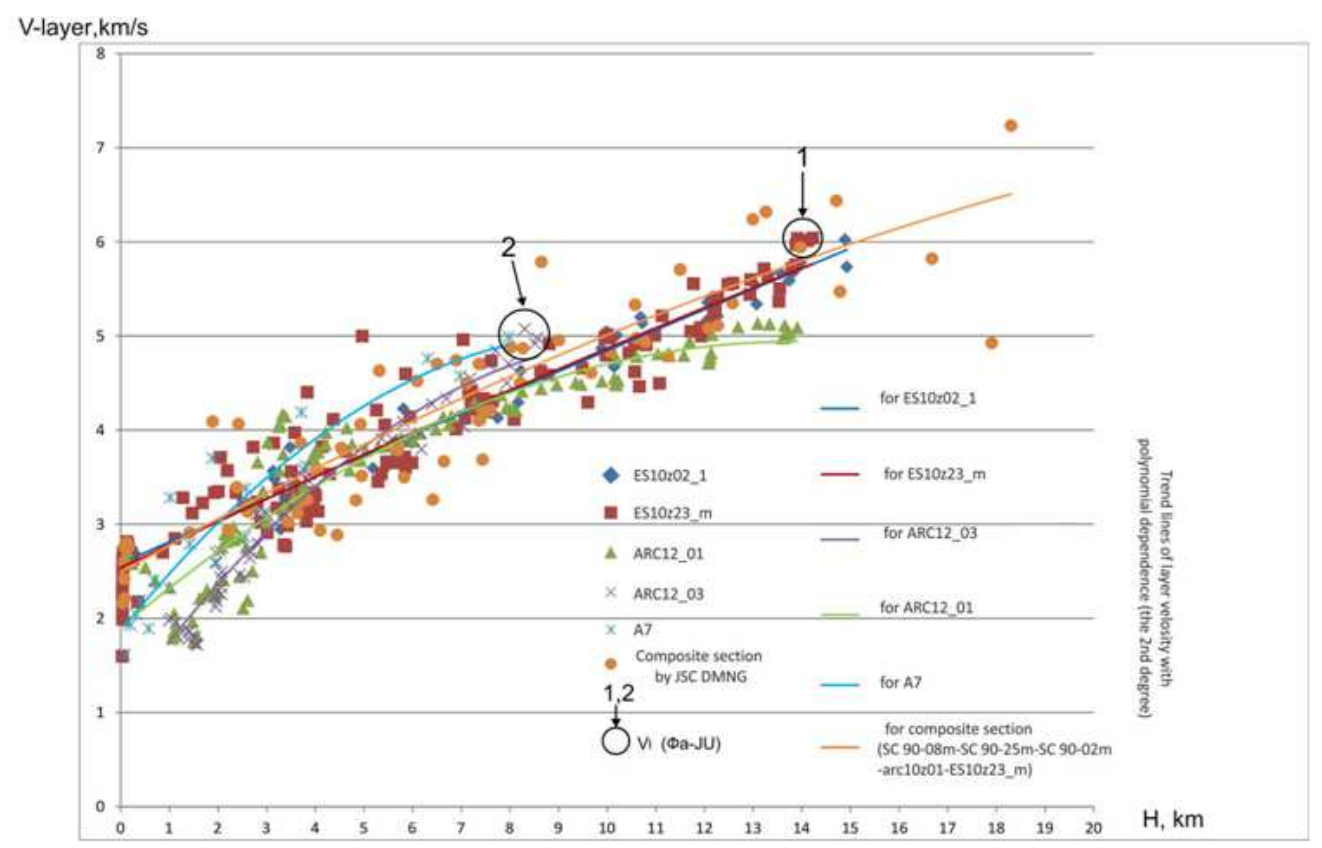

Fig. 9. Dependence diagram of layer velocity variation $V=F(T o)$ 


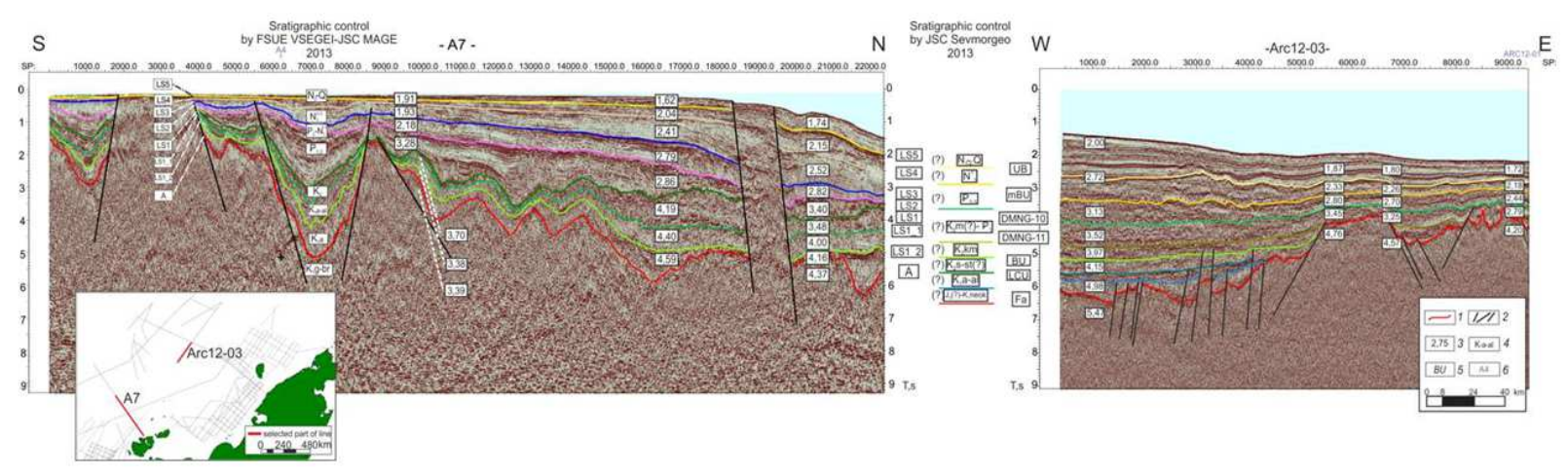

Fig. 10. Comparison of seismic lines wave field: A7 line and western part of the Arc12-03 line (interpretation of authors) 1-RH, 2faults, 3-interval velocity, 4-age, 5-RH name, 6-profile crossing point

The Podvodnikov basin is divided on two areas-east and west. The western part is partly displayed on the profile A-7 in the area of continental slope. We have made an attempt to compare the western part of the profile Arc12-03 with the profile A-7 in the area where there is a maximal thickness of sedimentary cover (Fig. 10). These wave fields are partially correlated (in the upper part). But the structures of these wave fields evidently differ in dynamics (Fig. 10) and kinematics (Fig. 9), especially in dynamic characteristics (QSSS quantity, its characteristics). On the profile A-7 the sedimentary cover starts with the sequence, related to Aptian deposits of Lower Cretaceous and according to our stratigraphic correlation the basement age here is Aptian. Thus the general thickness of sedimentary cover in the deepest part is almost equal.

\section{Results}

Firstly, it seems that the Vilkitskiy (western part of profile Arc12-03) and the North-Chukchi (north parts of profiles 5-AP, ES 10z23m, ES10z22m) troughs have similar structure of wave fields, dynamic and kinematic characteristics. On the basis of this it is reasonably to suggest that the Vilkitsky trough is not an independent structure but a near-flank part in the north of the WestChukchi trough. On the whole, northwards it joins the east part of the Podvodnikov basin.

In addition, we may suppose that the area of variously aged basement shall be aligned somewhere along the Podvodnikov basin (probably, the Geophysics Spur). This boundary might be found on the profiles Arc12-16, Arc11-065_14, Arc11-053_14. Unfortunately the technique of field operations on these profiles (streamer is less than $600 \mathrm{~m}$ ) does not allow solving this question now. In the published studies about the seismic profile 89-01 (LARGE), such border had been identified since 2001 (Drachev et al., 2001; Vinogradov et al., 2004).

\section{Conclusion}

It is to be noted that we are convinced that the usage of general geological reasoning for stratigraphic assignments and correlation of the key seismic horizons have low accuracy. The general reasoning as a rule are based on paradigms which can be neither proved nor refuted. The specific regional studies should be based on accurate continuous tracing of RH and QSSS and their dynamic and kinematic characteristics over the lateral and through a section. Geological point of view must only limit the geophysical models. For such closed and hardly-reached territory as the East Arctic, this is the only way to solve the aimed tasks.

\section{Acknowledgement}

Researchers are grateful to Company Total S.A. and JSC Dalmorneftegeophysica Azad University Sari branch for support this research.

\section{Author's Contributions}

Lidia Daragan-Sushchova: Designed the study, collected data and made the interpretation.

Lyudmila Grinko: Collected data and made the interpretation, edited the manuscript and prepare figures.

Natalia Petrovskaya: Wrote the manuscript.

Yuri Daragan-Sushchov: Wrote the manuscript.

\section{Ethics}

This article is original. All authors have read and approved the manuscript and no ethical issues involved.

\section{References}

Backman, J., K. Moran, D.B. McInroy and L.A. Mayer, 2006. Sites M0001-M0004. Proceedings of the Integrated Ocean Drilling Program, (ODP' 06), Washington, DC, IODPMI, Inc., pp: 169-169. DOI: 10.2204/IODP.PROC.302.104.2006 
Butsenko, V.V., 2008. Main tectonic events in the history of the Arctic Ocean based on seismic data. PhD Thesis, St. Petersburg, Russia.

Butsenko, V.V. and V.A. Poselov, 2004. Regional Peculiarities of Seismic Configuration of the Sedimentary Cover of the Deep-Water Arctic Basin and Possibility of its Paleotectonic Interpretation//Geological-Geophysical

Characteristics of the Arctic Crust. 5th Edn., St. Petersburg, Russia, pp: 159.

Chernih, A.A. and A.A. Krylov, 2011. Sedimentogenesis in the amundsen basin from geophysical data and drilling results on the lomonosov ridge. Doklady Earth Sci., 440: 1372-1376. DOI: $10.1134 / \mathrm{S} 1028334 \mathrm{X} 11100011$

Daragan-Sushchova, L.A., O.V. Petrov, Y.I. DaraganSushchov and D.D. Rukavishchnikova, 2010. New view on the geological structure of sedimentary cover of the Laptev Sea. Regional Geol. Metallogeny, 41: 5-1.

Daragan-Sushchov, Y.I., L.A. Daragan-Sushchova and V.A. Poselov, 2004. To subdivision issue of sedimentary cover of the Eurasian basin of the Arctic Ocean.

Drachev, S.S., A.V. Elistratov and L.A. Savostin, 2001. Structure and seismostratigraphy of the east siberian sea shelf along the indigirka bay-jannetta island seismic profile. Doklady Earth Sci., 377: 293-297.

Enachescu, M.E., 1990. Structural setting and validation of direct hydrocarbon indicators for amauligak oil field, Canadian Beaufort Sea. Am. Associat. Petrol. Geol. Bulletin, 74: 41-59. DOI: 10.1306/0C9B22091710-11D7-8645000102C1865D
Franke, D., K. Hinz and O. Oncken, 2001. The Laptev sea rift. Mar. Petrol. Geol., 18: 1083-1127. DOI: 10.1016/S0264-8172(01)00041-1

Jokat, W., E. Weigelt, Y. Kristoffersen, T. Rasmussen and T. Schöone, 1995. New insights into the evolution of the Lomonosov Ridge and the Eurasian Basin. Geophys. J. Int., 122: 378-392. DOI: 10.1111/j.1365-246X.1995.tb00532.x

Kim, B.I. and Z.I. Glezer, 2007. The sedimentary cover of the Lomonosov ridge (stratigraphy, history of cover and structure development, seismic sequences age dating). Stratigraphy Geological Correlation, 15: 63-83.

Langinen, A.E., D.G. Gee, N.N. Lebedeva-Ivanova and Y.Y. Zamansky, 2009. Correlations between the Lomonosov Ridge, Marvin Spur and adjacent basins of the Arctic Ocean based on seismic data. Tectonophysics, 472: 309-322. DOI: $10.1016 /$ j.tecto.2008.05.029

Rekant, P.V. and E.A. Gusev, 2012. Seismic geologic structure model for the sedimentary cover of the Laptev Sea part of the Lomonosov Ridge and adjacent parts of the Amundsen Plain and Podvodnikov Basin. Russian Geol. Geophys., 53: 1150-1162. DOI: 10.1016/J.RGG.2012.09.003

Sherwood, K.W., 2006. Structure of Hanna Trough and Facies of Ellesmerian Sequence, U.S. Chukchi Shelf, Alaska. Geol. Society Am., 38: 85-85.

Vinogradov, V.A., Gusev, B.G. and T. Lopatin, 2004. The age and structure of sedimentary cover of the East-Arctic RF Shelf. VNIIOkeanologia. 